\title{
Struma ovarii - a dermoid and serous form of ovarian cyst
}

\author{
Dobrosława Sikora-Szczęśniak, Wacław Sikora \\ Department Obstetrics and Gynecology, RSzS, Radom, Kielce \\ Head of Department: Dr. Zenon Michalak
}

Studia Medyczne 2013; 29 (3): 267-272

Key words: ovarian thyroid goiter.

\begin{abstract}
Struma ovarii belongs to the class of monodermal and highly specialized teratomas. These tumors are detected mainly among mature teratomas, accounting for up to $3 \%$ of all ovarian teratomas. Besides dermoid cysts, thyroid tissue is also found in serous and mucous cysts within the ovary. The aim of the research was to analysis of the incidence of struma ovarii - a rare type of tumor - among dermoid and serous ovarian cysts. Medical documentation of female patients subjected to surgery in the Department of Gynecology and Obstetrics, Independent Public Health Care Institution in Lipsko over a period of 17 years was reviewed for cases of struma ovarii. Struma ovarii was detected in 4 out of 103 operated females with dermoid and serous cysts. Thyroid tissue and serous cyst with a double-twisted pedicle were detected in a 22 -year-old patient in the $10^{\text {th }}$ week of gestation within the left ovary. In three cases of patients aged 42,46 , and 51, thyroid tissue encapsulated in dermoid cells was also located on the left side. All diagnoses were made on the basis of histopathological assessments. In a 17-year observation period, gestational struma ovarii was identified in one out of 17,751 patients whose pregnancies led to delivery. This accounts for $0.0068 \%$ of pregnancies ending with delivery. Struma ovarii was detected in one half of the patients in whom dermoid cells were detected bilaterally.
\end{abstract}

\section{Introduction}

In histogenetic terms, malignant ovarian goiter (struma ovarii) belongs to the class of monodermal teratomas. The term struma ovarii refers to tumors in which the thyroid tissue is the only microscopic structural component, as well as tumors in which the thyroid tissue is the major, albeit not the only component of the teratoma [1]. These tumors are detected mainly among mature teratomas, in women between 50 and 60 years of age [2].

About $20 \%$ of mature teratomas contain small amounts of thyroid cells [3]. Twenty percent of these tumors are built of thyroid tissue only. Besides dermoid cysts, thyroid tissue is also found in serous and mucous cysts within the ovary [1].

The content of iodine in the ovarian thyroid tissue is usually lower than in the normal gland; in one of the cases, no iodine is detected at all.

According to different authors, about 5 to $10 \%$ of thyroid goiter teratomas are accompanied by symptoms of thyrotoxicosis [1, 2, 4]. According to Skałba [3], struma ovarii is responsible for the full set of thyrotoxicosis symptoms in about $5 \%$ of cases.

Symptoms of hyperthyroidism resolve following the ectomy of the ovarian tumor containing thyroidlike tissue [5]. If the symptoms of hyperthyroidism (Graves' disease) persist after dissection of the tumor (struma ovarii), hormonally active metastases developing by local implantation of blood-mediated transfer into the peritoneum (strumosis peritonei), omentum, mesentery and liver should be taken into consideration. Such cases are observed in about 5-10\% of patients [6-8]. Ovarian goiter, along with malignant chorionic epithelioma that secretes human chorionic gonadotropin and pituitary adenoma that secretes thyroid-stimulating hormone (TSH), is a rare cause of hyperthyroidism [9]. Symptoms of hyperthyroidism and carcinoid syndrome may be present in strumal carcinoid that contains both thyroid and carcinoid tissue. This tumor, when present unilaterally in younger women who want to maintain their fertility, may be treated by unilateral adnexectomy [2]. Cases of malignant struma ovarii composed of adenocarcinoma tissue have also been reported [1, 3-5].

Surgical treatment of struma ovarii is associated with tumors containing thyroid tissue, as this type of tumor is usually diagnosed on the basis of histopathological examination. Treatment of both benign and malignant forms of struma ovarii consists of unilateral adnexectomy (if reproductive potential is to be conserved), or hysterectomy with adnexectomy. Metastases and recurrences are successfully treated with radioactive iodine ${ }^{131} \mathrm{I}[2,4,10,11]$.

The objective of the study was to determine the incidence of ovarian thyroid goiter (struma ovarii) a rare type of ovarian tumor - within the population of surgical patients. The study population consisted of two groups of female patients, a total of 103 patients. The first group consisted of 35 patients in whom ovarian dermoid cysts were identified upon the surgery. 


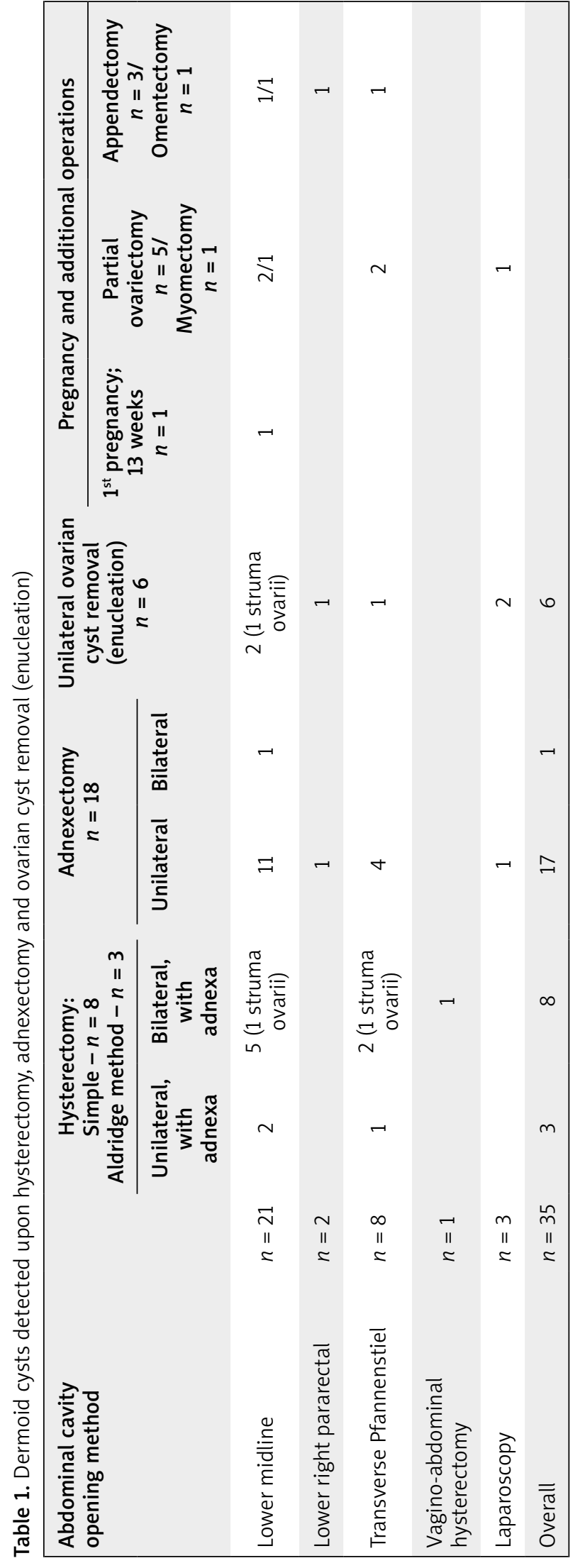

The other group included 68 patients presenting with ovarian serous cysts.

\section{Case reports}

The analytical material was collected in a retrospective fashion. The analysis was based on medical histories, surgical protocols, histopathology results and hospital discharges of female patients undergoing surgery, in whom ovarian thyroid goiter was found upon hysterectomy, adnexectomy or ovarian cyst removal (enucleation). Follow-up interviews were also made with patients with regard to their post-operative history several years or as much as decades after the procedures. The follow-up period ranged from 12 to 24 years.

Over a period of 17 years (1985-2001), 836 gynecological operations were performed by laparotomic techniques at the Department of Gynecology and Obstetrics, Independent Public Health Care Institution in Lipsko [11]. In 103 patients ovarian cysts were found, including 35 cases of dermoid cysts and 68 cases of serous cysts. Thyroid tissue presence was identified in $4(3.9 \%)$ patients.

Tables 1 and Table 2 present the details of the operations performed in patients with dermatoid and serous cysts, respectively.

Thyroid tissue presence was detected in 3 (8.6\%) cases of patients with dermatoid ovarian cysts. Unilateral dermoid ovarian cysts were found in $31(88.6 \%)$ patients, while bilateral dermoid ovarian cysts were found in $4(11.4 \%)$ patients. Struma ovarii was identified in 2 of these 4 patients.

Torsion of the pedicle of the ovarian or adnexal dermatoid cyst was observed for 5 cysts (14.3\%) - respectively in $1(1 \mathrm{x}), 2(2 \mathrm{x})$ and $2(3 \mathrm{x})$ cases. The mean age of patients with the disorder was 40 years (range of 9-76 years).

No cases of dermatoid cysts co-occurring with serous ovarian cysts were observed. Co-occurrence of dermatoid cysts with paraovarian cysts was observed three times (twice on the same side as the dermoid cyst and once on the contralateral side).

Benign serous tumors are considered to be the most common ovarian tumors within the group [12]. Among these, struma ovarii was observed in $1(1.5 \%)$ case.

Unilateral presence of serous cysts was observed in $63(92.6 \%)$ women, while bilateral cysts were observed in 5 (7.4\%). Co-occurrence of serous ovarian cysts with serous paraovarian cysts was observed in 4 cases $(5.9 \%)$.

The mean age of patients with these disorders was 44 years (range of 18-76 years). Torsion of the pedicle of the serous ovarian or adnexal cyst was observed in 4 cases $(5.9 \%)$.

\section{Case 1}

Patient, aged 22, first pregnancy, 8-10 weeks was brought to the hospital by the emergency service due 
Table 2. Serous ovarian cysts detected upon hysterectomy and adnexectomy

\begin{tabular}{|c|c|c|c|c|c|c|c|c|c|}
\hline \multirow{3}{*}{$\begin{array}{l}\text { Abdominal } \\
\text { cavity } \\
\text { opening } \\
\text { method }\end{array}$} & \multirow{2}{*}{\multicolumn{2}{|c|}{$\begin{array}{c}\text { Hysterectomy: } \\
\text { Wertheim }-n=2 \\
\text { Simple }-n=10 \\
\text { Aldridge }-n=19 \\
\text { (including vagino-abdominal }-n=3 \text { ) } \\
\text { Supracervical hysterectomy }-n=3 \\
\text { Adnexectomy }-n=17\end{array}$}} & \multirow{2}{*}{\multicolumn{2}{|c|}{$\begin{array}{c}\text { Ovarian cyst } \\
\text { removal } \\
\text { (enucleation) } \\
n=17\end{array}$}} & \multicolumn{5}{|c|}{ Pregnancy and additional surgeries } \\
\hline & & & & & \multirow[t]{2}{*}{$\begin{array}{c}\text { Removal } \\
\text { (enucleation) } \\
\text { of paratubal } \\
\text { cyst, } \\
\text { unilateral } \\
n=4\end{array}$} & \multirow{2}{*}{$\begin{array}{c}1^{\text {st }} \text { pregnancy; } \\
10 \text { weeks } \\
\text { (ovarian cyst } \\
\text { and struma } \\
\text { ovarii) } 2^{\text {nd }} \\
\text { pregnancy; } \\
15 \text { weeks } \\
n=2\end{array}$} & \multirow[t]{2}{*}{$\begin{array}{c}\text { Tubal } \\
\text { preg- } \\
\text { nancy } \\
n=3\end{array}$} & \multirow[t]{2}{*}{$\begin{array}{c}\text { Appen- } \\
\text { dectomy } \\
n=5 / \\
\text { Myomec- } \\
\text { tomy } \\
n=2\end{array}$} & \multirow[t]{2}{*}{$\begin{array}{c}\text { Cholecy- } \\
\text { stectomy } \\
n=2\end{array}$} \\
\hline & $\begin{array}{c}\text { Unilateral, with } \\
\text { adnexa } \\
n=19\end{array}$ & $\begin{array}{c}\text { Bilateral, with } \\
\text { adnexa } \\
n=27\end{array}$ & $\begin{array}{c}\text { Unila- } \\
\text { teral } \\
n=13\end{array}$ & $\begin{array}{l}\text { Bila- } \\
\text { teral } \\
n=4\end{array}$ & & & & & \\
\hline $\begin{array}{l}\text { Lower } \\
\text { midline } \\
n=46\end{array}$ & 12 & 21 & 9 & 4 & 4 & 2 & 3 & $5 / 2$ & 1 \\
\hline $\begin{array}{l}\text { Lower } \\
\text { right } \\
\text { pararectal } \\
n=1\end{array}$ & & & & 1 & & & & & \\
\hline $\begin{array}{l}\text { Transverse } \\
\text { Pfannenstiel } \\
n=14\end{array}$ & 5 & 3 & 6 & & & & & 1 & \\
\hline $\begin{array}{l}\text { Transverse } \\
\text { Cohen } \\
n=44\end{array}$ & & 3 & & 1 & & & & & \\
\hline $\begin{array}{l}\text { Vaginal } \\
\text { hysterectomy } \\
\text { upper medial } \\
n=1\end{array}$ & 1 & & & & & & & & 1 \\
\hline $\begin{array}{l}\text { Laparoscopy } \\
n=2\end{array}$ & 1 & & 1 & & & & & & \\
\hline $\begin{array}{l}\text { Overall } \\
n=68\end{array}$ & 19 & 27 & 16 & 6 & & & & & \\
\hline
\end{tabular}

to left lower abdomen pain persisting since the previous day. Preliminary examination revealed a cysttype adnexal tumor, ca. $10.0 \mathrm{~cm}$ in diameter, reaching up to the umbilicus level. First menstruation at the age of 14, followed by irregular periods of 31-40 days, with 5 days of menstruation. Last menstruation on 30.03-05.04.1986. Laboratory results were normal.

The patient underwent surgery on 17.06.1986. Presence of ca. $250 \mathrm{ml}$ of clear, amber-colored fluid was detected within the peritoneal cavity. Uterine trunk size corresponding to 8-10 weeks of gestation. Left ovary with a serous cyst $10.0 \mathrm{~cm}$ in diameter and double-twisted pedicle. Left-sided adnexectomy was performed.

Histopathological examination: left adnexa - Cystoma serosum simplex et struma ovarii. Oviductus.

The patient received Kaprogest in the perioperative period. No complications in the post-operative period. The patient was discharged from the department with preserved pregnancy. On 30.12.1986, she gave natural birth to a son sized $3060 \mathrm{~g} / 52 \mathrm{~cm}$
(Apgar 10). Later on, the patient gave natural births to another two children.

\section{Case 2}

Patient, aged 51. The patient was qualified for elective surgery for recurrent menopausal bleeding.

Upon gynecological examination, the following deviations from the normal were identified: partially epidermoid erosion of the vaginal portion of the cervix in specular examination. Bimanual examination revealed cystic enlargement of the ovaries: left ovary ca. $6.0 \mathrm{~cm}$ in diameter, right ovary ca. $4.0 \mathrm{~cm}$ in diameter. The patient underwent surgery on 25.05.1988. Hysterectomy and adnexectomy were performed.

Histopathological examination: uterine trunk Endometriosis corporis uteri. Endometrium atrophicans, cervix - Erosio glandularis in statu epidermisationis cum inflammatione, left adnexa - Cystis epidermalis et struma ovarii. Oviductus, right adnexa - Cystis epidermalis et cystes folliculares ovarii. Oviductus.

No complications in the post-operative period. 


\section{Case 3}

Patient, aged 46 was admitted to the department for surgical treatment of uterine myomas.

Gynecological examination using the speculum revealed erosion of the vaginal portion of the cervix. Bimanual examination: uterine trunk sized $12.0 \mathrm{~cm} \times$ $10.0 \mathrm{~cm}$, rough surfaces and of reduced mobility. Adnexa examined on both sides; cysts sized ca $6.0 \mathrm{~cm}$. On 26.02.1992, a surgical procedure including hysterectomy and adnexectomy was performed.

Histopathological examination: uterine trunk - Leiomyomata intramuralia corporis uteri multiplicia corporis uteri. Endometrium in stadio secretionis, cervix - Erosio cystica in statu epidermisationis cum inflammatione, left adnexa - Cystis epidermalis et struma ovarii. Salpingitis chronica, right adnexa - Cystis ectodermalis ovarii. Salpingitis chronica.

Despite the fact that the surgery was performed upon moderate acute normovolemic hemodilution, erythrocyte mass transfer $(850 \mathrm{ml})$ was required on the third day after the procedure due to ischemia.

\section{Case 4}

Patient, aged 42 was referred to the department due to left ovarian cyst diagnosed in an outpatient setting.

Gynecological examination aimed at identification of deviations from the normal revealed a smooth, moving resistance within the left adnexa, ca. $6.0 \mathrm{~cm}$ in diameter. Results of additional tests were unremarkable. The patient underwent surgery on 23.07.1998 Enucleation of the left and right ovarian cysts was performed and a specimen of the right ovary was collected for histopathological examination.

Histopathological examination: cyst of the left ovary - Struma in cystomate ectodermalis et cystes folliculares ovarii, specimen of the right ovary - Cystes folliculares ovarii.

No complications were observed in the early postoperative period.

\section{Discussion}

Struma ovarii was found within a serous cyst in 1 case and within dermatoid cysts in 3 cases. The incidence of serous cysts was nearly twice as high as that of dermatoid cysts. This was consistent with the conclusion drawn by Hillard [12], namely that serous adenocystomas are the most common benign ovarian tumors.

The presence of thyroid tissue was discovered in $8.6 \%$ of females with ovarian dermoid cysts; this value was higher than that of up to $3 \%$ as reported in the literature [6, 7].

Baker [2] reports that dermoid cysts are bilateral in more than $15 \%$ of cases. Templeman et al. reported the incidence of bilateral dermoid cysts at the level of $10 \%$ [13]. Vercellini et al. [14] reported that in women of childbearing potential, bilateral location was observed in $13 \%$ of cases for teratomas and in $7.2 \%$ of cases for serous cysts.

In our patients, bilateral location of both types of cysts was observed in $11.4 \%$ and $7.4 \%$, respectively. Importantly, 2 cases of struma ovarii were observed in patients with bilateral dermoid cyst location.

The risk of dermoid cyst torsion is $15 \%$, which is the highest rate for all benign tumors [13]. In our study material, this complication was observed in $14.3 \%$ and $5.9 \%$ for dermoid and serous cysts, respectively. Torsion of the pedicle of the left ovary with the presence of thyroid tissue and a serous cyst were reported in a patient in the tenth week of her first pregnancy. Surgical treatment (laparoscopy or laparotomy) of struma ovarii, usually present within a dermoid cyst, remains an open issue [15]. The preferred method involves the removal of the ovarian cyst itself, particularly in younger patients, even if the ovarian tissue left after the surgery is very small $[13,16]$.

Conditions for laparoscopic removal of dermoid cysts are more difficult than those for other benign ovarian tumors. Rupture and leaking of the dermoid cyst contents into the peritoneal cavity may put the patient at risk of the rare but dangerous complication of chemical peritonitis. The sebum content of dermoid cysts is very irritating to the peritoneum. If the contents of the cyst leak into the peritoneal cavity during the procedure, careful and repeated lavage of the peritoneum is required [15-17].

According to other authors, intra-operational evacuation of the contents of the cyst into the peritoneal cavity rarely leads to complications [18-20].

Malignant transformation develops in $2 \%$ of dermatosis cells, in most cases in women above the age of 40. Malignant forms of struma ovarii account for $5 \%$ of cases $[13,15]$. However, atypical thyroid cells within ovarian tumors are rare; they may also be treated with radioactive iodine $\left.{ }^{(131} \mathrm{I}\right)$ [21]. The risks of chemical peritonitis and malignant transformations are limitations for laparoscopic treatment.

Considering the potential complications following conservative surgical treatment, some authors recommend radical surgery upon the diagnosis of struma ovarii [22]. However, conservative surgery with possible adjuvant radioactive iodine treatment, if necessary, seems to be justified in women of reproductive potential $[16,21]$.

In cases of malignant struma ovarii, adjuvant treatment with ${ }^{131} \mathrm{I}$ is required following conservative surgical treatment. In these cases, cryoconservation of ovarian tissue is performed in women of reproductive potential treated with ${ }^{131} \mathrm{I}$ in order to preserve their fertility [23].

Surgical treatment of genital organ disorders suspected of neoplastic character should be performed at sites where intraoperative examinations are possible. 
This is particularly important in ovarian tumors in girls and women of reproductive potential in whom therapeutic management should be as safe as possible so as to preserve their fertility. However, recommendations to perform fertility conserving surgery only in highest-level referral units are not always feasible. Some hospitalized patients require immediate surgical intervention or are admitted to emergency rooms (where histopathological examination is impossible even at tertiary referral sites). Another complication is due to the condition of affected organs (adnexa) upon ovarian tumor torsion. In such cases hemorrhagic and necrotic lesions make correct macroscopic assessment of the disease more difficult [24].

In our materials, no symptoms of hyperthyroidism or other tumors were observed, including the post-operative period. In the last few years, 7 cases of struma ovarii were reported in available Polish literature $[6,7,25]$.

The literature contains only isolated cases of struma ovarii in pregnancy [26]. No reports were found in the available literature with regard to patients in the first trimester in pregnancy undergoing surgery for emergency reasons (due to torsion of the adnexal pedicle with struma ovarii).

In the presented material, spanning a period of 17 years, struma ovarii was diagnosed in as few as four cases within dermoid and serous ovarian cysts, accounting for $8.6 \%$ and $1.5 \%$ tumor incidence, respectively. The relatively small size of the study material is due to the fact that struma ovarii is a rare tumor, most commonly detected incidentally in histopathological examination.

Currently, possibilities for preoperative detection of struma ovarii type tumors have been expanded by ultrasonographic techniques, including color Doppler transvaginal ultrasound scans. In contrast to dermoid cysts, the image of struma ovarii includes vascularization of not only the capsule, but also the mesenchyma of the tumor, with resistance index (RI) values of less than 0.6 [7].

\section{Conclusions}

In a 17-year observation period, gestational struma ovarii was identified in one out of 14,751 patients whose pregnancies led to delivery. This accounts for $0.0068 \%$ of pregnancies ending with delivery. Struma ovarii was detected in one half of the patients in whom dermoid cells were detected bilaterally.

\section{References}

1. Szamborski J, Jajnik. In: Histopatologia ginekologiczna Kobuszewska-Faryna M, Szamborski J (eds.). PZWL, Warsaw 1974; 219-319.

2. Baker TR. Nowotwory germinalne jajnika. In: Podręcznik ginekologii onkologicznej. Piver MS (eds.). Wydawnictwo Lekarskie PZWL, Warsaw 1999; 54-75.
3. Skałba P. Hormonalnie czynne guzy jajnika. In: Endokrynologia ginekologiczna. Skałba P (ed.). PZWL, Warsaw 1989; 180-186.

4. Kędzia H. Nowotwory germinalne jajnika. In: Nowotwory narządów płciowych kobiety. Kędzia H (ed). OWN, Poznań 1997; 83-100.

5. Pisarski T, Simm S, Wolna M. Onkologia ginekologiczna. In: Ginekologia. Klimek R (ed.). PZWL, Warsaw 1982; 194-331.

6. Sidor M, Goluda C, Bielanów T. Struma ovarii - nowotwór jajnika. Ginekol Pol 1997; 68: 499-501.

7. Sarap J, Szymański M, Grabiec M. Struma ovarii - rzadko spotykany nowotwór jajnika. Ginekol Pol 1998; 69: 294-297.

8. Tsukada Y. Histopatologia nowotworów złośliwych narządów rodnych. In: Podręcznik ginekologii onkologicznej. Piver MS (ed.). Wydawnictwo Lekarskie PZWL, Warsaw 1999; 396-433.

9. Daberkow II DW, Nolan TE. Podstawowa opieka w ginekologii. In: Ginekologia. Berek JS, Novak E (eds.). MediPage, Warsaw 2008; 227-265.

10. Rzepka-Górska I, Błogowska A, Zajączek S, et al. Nowotwory germinalne $\mathrm{u}$ dziewcząt i młodych kobiet. Ginekol Pol 2003; 74: 840-846.

11. Sikora W, Szczęśniak G, Sikora-Szczęśniak DL. Ewentracja po operacjach ginekologicznych. In: Reoperacje w ginekologii. Jakowicki JA (ed.). Wydawnictwo BiFolium, Lublin 2004; 227.

12. Adams Hillard PJ. Łagodne choroby żeńskich narządów płciowych. In: Ginekologia. Berek JS, Novak E (eds.). MediPage, Warsaw 2008; 473-556.

13. Templeman CL, Fallat ME, Lam AM, et al. Managing mature cystic teratomas of the ovary. Obstet Gynecol Surv 2000; 55: 738-745.

14. Vercellini P, Pisacreta A, Vicentini S, et al. Lateral distribution of nonendometriotic benign ovarian cysts. $\mathrm{Br} \mathrm{J} \mathrm{Ob-}$ stet Gynaecol 2000; 107: 556-558.

15. Rzepka-Górska I. Nowotwory germinalne jajnika. In: Ginekologia onkologiczna. Markowska J (ed.). Wydawnictwo Medyczne Urban\&Partner, Wrocław 2006; 949-958.

16. Rzepka-Górska I. Nowotwory nienabłonkowe jajnika. In: Ginekologia onkologiczna. Markowska J, Mądry R (eds.). Med Pharm Polska, Wrocław 2008; 207-218.

17. Achtari C, Genolet PM, Bouzourne H, et al. Chemical peritonitis after iatrogenic rupture of a dermoid cyst of the ovary treated by coelioscopy. Apropos of a case and rewiev of the literature. Gynaecol Gebusthilf Rundsch 1998; 38: 146-150.

18. Yuen PM, Yu KM, Yip SK, et al. A randomized prospective study of laparoscopy and laparotomy in the management of benign ovarian masses. Am J Obstet Gynecol 1997; 177: 109-114.

19. Mecke H, Savvas V. Laparoscopic surgery of dermoid cyst intraoperative spillage and complications. Eur J Obstet Gynecol Reprod Biol 2001; 96: 80-84.

20. Campo S, Garcea N. Laparoscopic conservative excision of ovarian dermoid cysts with and without an endobag. J Am Assoc Gynecol Laparosc 1998; 5: 165-170.

21. Sobotkowski J. Radioterapia guzów germinalnych i gonadalnych jajnika. In: Ginekologia onkologiczna. Markowska J (ed.). Wydawnictwo Medyczne Urban\&Partner, Wrocław 2006; 967-972. 
22. Krawczuk A, Szamatowicz M. Gonada żeńska. Jajnik. Przedwczesne dojrzewanie płciowe. In: Endokrynologia kliniczna. Hartwig W (ed.). PZWL, Warsaw 1984; 943-1017.

23. Salvatori M, Dambra DP, D'Angelo G, et al. A case of metastatic struma ovarii treated with 131I therapy: focus on preservation of fertility and selected review of the literature. Gynecol Endocrinol 2008; 24: 312-319.

24. Szymański M, Socha MW, Szymański W, et al. Operacje zachowujące płodność (FSS) u pacjentek z nowotworami złośliwymi jajników. Ginekol Prakt 2005; 13: 2-7.

25. Hirowska-Tracz M, Gasińska-Drozdowska I, Gabryś M, et al. Guzy jajnika u dziewcząt i młodych kobiet w materiale własnym. Ginekol Pol 2003; 74 (Suppl. 1): 52.

26. Sifakis S, Panayiotides IG, Angelakis E, et al. Benign struma ovarii complicating pregnancy: a case report and review of the literature. Arch Gynecol Obstet 2003; 269: 72-73.

\section{Address for correspondence:}

Dobrosława Sikora-Szczęśniak

Department Obstetrics and Gynecology RSzS Radom

ul. Tochtermana 1, 26-600 Radom, Poland

E-mail: sikorawa@wp.pl 